\title{
European Practice of Conflict Settlement in the South Caucasus: Philosophical and Methodological Aspects
}

\author{
Kamilla K. Dadashova, Nazim N. Abdullayev \\ Moscow State Institute of International Relations (MGIMO- \\ University) of the Ministry of Foreign Affairs of the \\ Russian Federation \\ Moscow, Russia
}

\author{
Nail H. Kashaev \\ Bashkir State University \\ Ufa, Russia \\ Dmitriy A. Karev, Aleksei N. Churakov \\ Samara State University of Economics \\ Samara, Russia
}

\begin{abstract}
The article analyses the key aspects of certain theories devoted to European integration processes, the impact of these processes on $\mathrm{EU}$ peacekeeping activities regarding conflicts in the South Caucasus, evaluates the results of European peacekeeping missions in this region. Special attention is also paid to the factors that determine the degree of activity of the association in the region, to the tools and tactics of influence which EU uses in order to prevent the escalation of conflicts.
\end{abstract}

Keywords - conflict resolution; European integration; theories of European integration; regional cooperation; Azerbaijan; Armenia; Georgia; South Caucasus; EU

\section{INTRODUCTION}

In the last decade of the 20th century, one of the most characteristic threats to the stability and well-being of states was the increase of ethno-political conflicts. With the collapse of the Soviet Union in the South Caucasus has developed three open unresolved conflicts: 1) Nagorno-Karabakh, 2) GeorgianOssetian, 3) Georgian-Abkhazian. Historically, global and regional players had geopolitical, economic and energy interests in this region, their aim was to minimize possible damages in case of renewed hostilities.

After a large-scale European Union (EU) enlargement in 2004 and the well-known events of August 2008, the EU began to position itself as an active mediator in the conflicts in the South Caucasus. A more visible involvement of the union was connected with the need to stabilize the nearest outer periphery and establish itself as one of the world centers.

At the same time, it is obvious that in the first years of the fragmentation of the former Soviet space, Brussels did not dare to take serious peacemaking initiatives. Understanding of the integration processes reveals the nature of European participation in the settlement of conflicts in the South Caucasus

\section{METHODOLOGY}

The methodological basis of the presented work is the theory of structural realism (neorealism), neofunctionalism and intergovernmentalism, which contribute to a comprehensive analysis of the relations between the EU and the republics of the South Caucasus at various levels and in individual areas of cooperation. In addition, the work will use both general scientific analytical methods and a number of methods related to conducting research on international relations, namely: analyzing sources and analytical materials, comparing data, synthesizing information, interviewing experts. The article was also based on such fundamental principles as objectivity, comprehensive analysis of the problem and historicism

\section{LITERATURE REVIEW}

The European Union is a complex multi-level structure and the most remarkable integration association of European states. There is no unified theory covering all the elements of integration, but most existing theories complement each other, reflecting the diversity of individual aspects. That's why it is important first of all to define the term "integration". In this study, political integration between states means "the formation of some integral complex at the level of political systems" [1].

The tradition of political realism is rooted in the Renaissance philosophy, its principles can be found in the writings of Montesquieu, Kant and Smith. An extensive array of observations accumulated with political realism allows to comprehend the processes of geopolitical transformation in the modern world. Batalov [2] regards realism not only as another research paradigm among numerous others, but as one that claims to be the dominant theory in the science of international relations.

From the point of view of structural realism, the notion of threat determines the dynamics of European integration. Waltz in his famous work "The Man, the State and the War", puts forward the idea of a structural triad [3]. First, he points to survival as a common and main goal for all states which take into account only their own interests. Secondly, according to this paradigm, nation states are the only participants of international relations. Third, Waltz concludes that changing the balance of the system is associated with the desire of states to have greater potential.

The theory of liberal intergovernmentalism of Moravchik [4] calls the process of European integration a "two-level game". The key factor in political and economic convergence on the European continent is according to him the realization of the interests of the three powerful and most influential member countries: Germany, Great Britain and France. Integration itself occurs when socio-political groups are formed within the state. 
Then, during the intergovernmental negotiations, the leaders defend the state interests, seeking the most favorable conditions that meet the needs of national interest groups.

The doctrine of neofunctionalism was developed by American political scientist Haas [5] and received its continuation in the works of Schmitter [6]. The ideas of this theory boil down to the fact that it is the political tools that serve the achievement of economic goals. It is based on two principles: the spill-over effect and supranationality. The first implies that success in one sector of the economy extends to other industries. The impetus is political will. Schmitter also stressed that this mechanism leads to the "overflowing" of social and economic integration into the political sphere. The second principle focuses on the activities of non-state actors, including interest groups, regional bureaucratic elites and social movements. In contrast to neorealism, the key role is played not by the member states, but by the leadership of the organization, since it is responsible for the development of ideology and creation of the bureaucratic apparatus. Thus, common interests are formulated from the position of supranationality and are realized within the framework of supranational institutions.

In general, a common point, traced in the approaches to understanding European integration, is the existence of a coherent political system. Within the framework of such a system, decisions are implemented on the basis of compromises and balanced interests.

\section{RESULTS AND DISCUSSION}

From the point of analysis of the nature and dynamics of integration processes in Europe, cooperation between member states is carried out in full on issues of common value to them. National interests occupy a priority position, especially in the areas of high politics (foreign policy, security).

Other actors, inside or outside a participating country, also have a certain impact. According to neorealism and intergovernmentalism, this impact is insignificant. Neofunctionalism, on the contrary, speaks of the strong influence of various actors, including supranational elites, institutions and non-governmental organizations, both on integration processes and on the perception of state interests.

The South Caucasus is not among the priority foreign policy directions of the European Union. The involvement of the EU in the process of conflict resolution in the region has been observed since 1993 within the framework of the United Nations and the Organization for Security and Co-operation in Europe (OSCE). At the same time, the efforts made to bring conflicts into the course of negotiations were not even. The focus was on conflicts in Georgia. In particular, the EU from the very beginning unequivocally supported the territorial integrity of Georgia, while in the formulations on the NagornoKarabakh conflict manifested duality. Thus, in the Action Plan signed with Azerbaijan [7], the guiding principle was the respect for sovereignty and territorial integrity, while in the Action Plan signed with Armenia [8] - the right to selfdetermination. Gradually, ties with the three republics expanded and it required a review of the role of European countries in resolving conflicts in the region.
By the end of the 1990s EU foreign policy has acquired clear contours. The Maastricht [9] and Amsterdam [10] treaties set out two key elements: the Common Foreign and Security Policy (CFSP) and the institution of the High Representative for the Common Foreign and Security Policy. Regarding the South Caucasus, the European position was to preserve the status quo and prevent the escalation of tensions. The interest of member countries was stimulated mainly by the implementation of energy projects. The conjuncture of the European market of fuel and energy resources indicated the need to diversify the sources and ways of energy supply. Among other factors that determine European interest in the South Caucasus were the activity of the Armenian diaspora in some European countries and the possible entry of Turkey into the union. The restraining factor was the reluctance to intervene in the region, which traditionally belongs to the sphere of Russian interests, as it could have a negative impact on relations between Brussels and Moscow.

In the 2000s. on the agenda was the issue of the expansion of the European Union to the East and the inclusion of neighboring countries, including Azerbaijan, Armenia and Georgia, into European programs. Ideas for creating a zone of stability and well-being were reflected in such projects as the European Neighborhood Policy and the Eastern Partnership. The task of strengthening security in the South Caucasus and taking a more active role in resolving conflicts received specific justification in a number of resolutions of the European Parliament, for example, in the resolution "On strengthening the European Neighborhood Policy" (November, 2007) [11] or the resolution "On the need for an EU strategy for the South Caucasus " (May, 2010) [12]. The opinion has gained popularity that cooperation on economic, social and other practical issues (low politics) will expand the horizons of cooperation in the areas of high politics (security, foreign policy), which in turn will create favorable conditions for peace and conflict resolution.

Nevertheless, in practice, peacekeeping activities were declarative in nature and no serious measures were taken by the EU. The only successful initiative was the development of agreements during the war between Russia and Georgia in 2008. At the same time, trust between the West and the Russian Federation was severely damaged. The keynote of European policy in the South Caucasus was the weakening of its dependence on energy imports from Russia. Therefore, it was necessary to establish closer economic relations with the three republics, gradually integrating them into the European space and protecting the energy infrastructure.

The analysis showed that initially the EU policy in the South Caucasus had a pragmatic nature, and was aimed at extracting the greatest possible benefit from the geostrategic position of the region. Conflict resolution was of secondary importance. The claim for geopolitical advance to the east required from the EU more concerted action in the region. Not only European companies engaged in the implementation of economic projects, but also directly the political elites and leadership of the member countries began to feel interested in securing the borders of the EU. The new programs set ambitious goals to engage the European Union in peacemaking activities in the South Caucasus. However, this did not bring 
any concrete results, since a number of contradictions within the EU limited its desire to intervene in peacemaking processes.

\section{CONCLUSION}

Thus, traditionally the integration processes on the European continent are explained within the framework of theories of structural realism, intergovernmentalism and neofunctionalism. In accordance with the proposed theories, the presence of the European Union in the South Caucasus and its role in the conflict resolution process is determined as follows. The initial indirect mediation role of the EU was due to a minor interest or a complete lack of interest from the part of the Member States. The entry of Eastern European countries has put on the agenda the issue of ensuring stability at the borders of the EU. The subsequent deepening of political and economic ties with the republics of the South Caucasus gave hope that the conflicting parties could be brought together on the basis of common projects. In modern conditions of EU peacekeeping activity in the South Caucasus lacks more effective tools for the creation of prerequisites for a successful dialogue.

\section{REFERENCES}

[1] V. G. Baranovsky, Political integration in Western Europe: some theoretical and practical issues. Moscow: Nauka, 1983. (In Russ.)

[2] E. Batalov, On the philosophy of international relations. Moscow: NOFMO Publ., 2005. (In Russ.)

[3] K. N. Waltz, Man, the State and War: Theoretical Analysis. N.Y. Columbia University Press, 1959.

[4] A. Moravcsik, "Explaining international human rights regimes: Liberal theory and Western Europe," European Journal of International Relations, vol. 1(2), pp. 157-189, 1995.

[5] E. Haas, and P. C. Schmitter, "Economics and Differential Patterns of Political Integration: Projections about Unity in Latin America," in International Political Communities: An Antology. New York: Doubleday, 1966, pp. 259-300.

[6] P. C. Schmitter, "Neo-neo-functionalism," 2002. Available online: https://www.eui.eu/Documents/DepartmentsCentres/SPS/Profiles/Schmi tter/NeoNeoFunctionalismRev.pdf

[7] European Union External Action, "EU/Azerbaijan Action Plan". Available online: https://eeas.europa.eu/sites/eeas/files/azerbaijan_enp_ap_final_en.pdf.

[8] European Union External Action, "EU/Armenia Action Plan". Available online: https://eeas.europa.eu/sites/eeas/files/armenia_enp_ap_final_en.pdf

[9] Treaty on European Union, 1992. Available online: https://europa.eu/europeanunion/sites/europaeu/files/docs/body/treaty_on_european_union_en.pdf

[10] Treaty of Amsterdam Amending the Treaty on European Union, the Treaties Establishing the European Communities and Certain Related Acts, $1997 . \quad$ Available online: http://www.europarl.europa.eu/topics/treaty/pdf/amst-en.pdf

[11] European Parliament Resolution of 15 November 2007 on strengthening the European Neighborhood Policy, 2007. Available online: http://www.europarl.europa.eu/sides/getDoc.do?type=TA\&language $=\mathrm{E}$ N\&reference=P6-TA-2007-538

[12] European Parliament Resolution of 20 May 2010 on the Need for an EU Strategy for the South Caucasus, 2010. Available online: http://www.europarl.europa.eu/sides/getDoc.do?pubRef=-

//EP//TEXT+TA+P7-TA-2010-0193+0+DOC+XML+V0//EN 